\title{
The War Guilt Clause and the Rise of Adolf Hitler
}

\author{
Stella Zhu
}

\begin{abstract}
After the fall of Nazi Germany during World War II, the allied powers issued harsh reparation payments that burdened the German economy and humiliated the Germans. Most importantly, the War Guilt Clause led Germany into an economic and social turmoil, which in turn paved the path for the rise of radical extremists like Adolf Hitler.
\end{abstract}

Index Terms - Adolf Hitler; Germany; Treaty of Versailles; War Guilt Clause.

\section{INTRODUCTION}

The notorious Article 231, also known as the War Guilt Clause, was a problematic clause in the Treaty of Versailles, a peace agreement signed on June 28, 1919, between Germany and the allies - Britain, the United States, France, Russia, and Italy — that formally ended World War I. The allies believed "[the Germans] must pay, they must pay heavily, and they will pay" (View Appendix I) [3]. The article gave the allies the right to enforce the provisions which made the treaty widely known as Diktat, a dictated peace. The article obligated Germany to admit the responsibility of starting World War I and pay back the allies for the losses of lives and damages of properties, even the actions of the allies (View Appendix II) [7]. Accepting all responsibility came at a heavy price. The harsh reparation payments burdened the economy, and the humiliation and betrayal angered the Germans; this anger led to the rise of radical extremists like Adolf Hitler. The War Guilt Clause led Germany into an economic and social turmoil, which in turn paved the path for the rise of Adolf Hitler.

\section{Harsh REPARATIONS}

First and foremost, the unspecified sum and the ever increasing harsh reparation payments severely burdened the German economy. The War Guilt Clause is the first article in the reparation section. Harry Elmer Barnes, an American historian, believed, "German reparations were explicitly and definitely based on the war guilt clause (231) of the Treaty of Versailles" [2]. However, it became problematic when the sum was not set in the treaty. John Maynard Keynes, coauthor of Article 231 and British economist, expressed in his memorandum entitled "Reparation and Indemnity," a memo that was widely accepted as the precursor of the War Guilt Clause, that Germany must be forced to pay reparations [13]. However, he alleged it is impossible to specify how much Germany can pay annually so the treaty has an unfixed amount of reparation [13]. The treaty also did not state how the allies would divide the reparation so the allies continued to debate how it should be divided and they made it clear that
Germans would continue to pay high quantities. The Germans were forced to sign a blank check which they viewed as indefinite slavery [13]. The unfixed payment continued to aggravate the German economy when the United States insisted on war debts on its allies, particularly France [4]. This made the Europeans pass their burden to Germany through high reparation payments, deepening the animosity of Germans (View Appendix III) [20]. France continued to bully the Germans to pay for the physical damages of the war since western warfare was fought mainly on French soil. France affirmed that they are not responsible for paying the reconstruction. The hostility between Germany and France continued to worsen and French leaders expressed that they desired a German nation that is unable to control Europe and the French themselves desired full power of Europe. Some French leaders were nervous and disturbed by this goal. Marshal Ferdinand Foch claimed, "This is not peace, it is an armistice for twenty years" [4]. The War Guilt Clause granted France the power to enforce their desire of increasing the sum in Germany. As a result, instead of rebuilding the German economy, such as rebuilding towns, and investing in German industries, like reopening mines, Germany had to pay the allies which the economy was not strong enough to do so. Without reconstructions, the rate of homelessness and poverty increased and with the loss of industries it further intensified the problem. The collapse of the German economy and the inability to compensate the allies on time eventually led Germany to an economic crisis in 1923. During that time, the hyperinflation exacerbated as more currency was printed to pay the wages of workers on strike in Ruhr valley, where France and Belgium's troops invaded the region aiming to confiscate industrial goods because of Germany's failure to pay reparations on time. Germany was already suffering from high levels of hyperinflation due to the effects of the war and growing government debt and when the hyperinflation continued to aggravate and the production line in Ruhr valley fell, it devastated the German economy. The War Guilt Clause led to financial instability which persuaded the middle and working-class to be more likely to listen to radical extremists such as Adolf Hitler for resolutions.

\section{ANNEXED TERRITORIES}

Moreover, when Article 231 granted the Allies the right to annex German territories, the Germans felt deeply humiliated. Referring to Appendix IV [14], note the territorial changes and which countries it was transferred to. Valuable lands that were given away worsened the economy. For example, the coalfield in the State of Saarland were given to France and the rice fields in Western and Eastern Prussia 
were also under foreign control. The loss of coalfields and rice fields meant that the Germans had to forfeit their wealth and food to enemies. Poland re-established as a new state and was given part of Western Prussia and the free city of Danzig was established which the allies intended to grant Poland access to the sea (View Appendix V) [12]. The creation of the Polish corridor that separated Germany from East Prussia was the most insulting. Germans also lost all of the colonies through mandates. In total, Germany lost $16 \%$ of its coalfields, $48 \%$ of its iron and steel industry, $13 \%$ of its land, and $12.5 \%$ of its original population was now living in another country [11], [15], [17]. Georges Clemenceau, the French Prime Minister, expressed a smaller country would be less of a problem [6]. Indeed, with all of these losses came the diminishing of power. Not long ago, during the German empire, Germany was one of the global superpowers. After the war, Germany had less land, people, money, and power which was a blow to German pride. The helplessness and the blow to German pride provoked nationalists to seek revenge and reclaim the pride.

\section{DEMILITARIZATION}

Furthermore, the clause allowed the disarmament of the German army, and the demilitarization further intensified the sense of humiliation the Germans felt. In the 1919 conference, among the allied governments the "German Question" was intensely discussed since they believed German militarism was one of the main causes of the devastating world war [20]. The reduction of military power was designed to weaken Germany so they would be unable to revive and declare another war. The army was limited to 100,000 men, 6 battleships, no air force, and no construction of armored cars, tanks, submarine fleets, and poison gas were allowed. This resulted in the incapability of Germany to even fight against other new small nations. In 1920, Germany sent troops to the Ruhr region to control uprisings but the French invaded soon after which forced the German army to leave. Again, unlike the time during the prosperous and strong German empire, this was a national insult because it demonstrated the incompetence of the German army. Hitler and Nazis further utilized this sense of humiliation to gain power.

\section{SENSE OF BETRAYAL}

Lastly, the rejection of full responsibility and helplessness intensified the sense of hatred, nationalism, and betrayal among the German citizens. The citizens were astonished by the War Guilt Clause and felt betrayed. Germany was excluded from the 1919 conference, and they believed it was unjust to bear all the burden. They firmly believed they bore no more guilt and responsibility than any other European power, so they rejected the accusation that they caused the war. They claimed the war was an act of self-defense against Russia and they insisted classified records from 1914 were published in the 1920s that showed the effort of the German government trying to prevent a war [19]. Philipp Scheidemann, a moderate Social Democratic leader, reacted to the War Guilt Clause saying, "What hand will not wither that delivers us into such chains" [4]? Those beliefs and indignations were escalated among the more radical and extreme politicians. However, when Germany refused to sign the treaty and tried to propose revisions to the clauses, the allies threatened to rage war. This sense of helplessness along with the realization of having a weak army force greatly helped unite Germans of all classes and political stances to work against the treaty, which led the German citizens to be more willing to accept extremists' ideas.

\section{CONCLUSION}

The incredibly harsh terms that were enforced on Germany by Article 231 created economic hardship and a sense of humiliation, indignation, nationalism, and betrayal. It further discredited the Weimar Republic that accepted the cause [4] and paved the way for extremist movements to feed on it and rile up the German people. The radicals gained support by spreading false information about the War Guilt Clause and lied about its impact since the public could not access the documents. Politicians claimed it implied guilt, which provoked the commoners and in turn led to more support for Nazis and Hitler, who promised to reclaim territories, restore the military, and regain dominance. The Nazis constructed a nation that was more autocratic and militaristic [17]. It eventually led to the Second World War, where the desire for world power and promises of reconquest and annexation were put into action.

\section{CONCLUSION}

A conclusion section is not required. Although a conclusion may review the main points of the paper, do not replicate the abstract as the conclusion. A conclusion might elaborate on the importance of the work or suggest applications and extensions.

\section{APPENDIX}

Appendix I. The Amaroc News claimed the Germans have to pay [3].

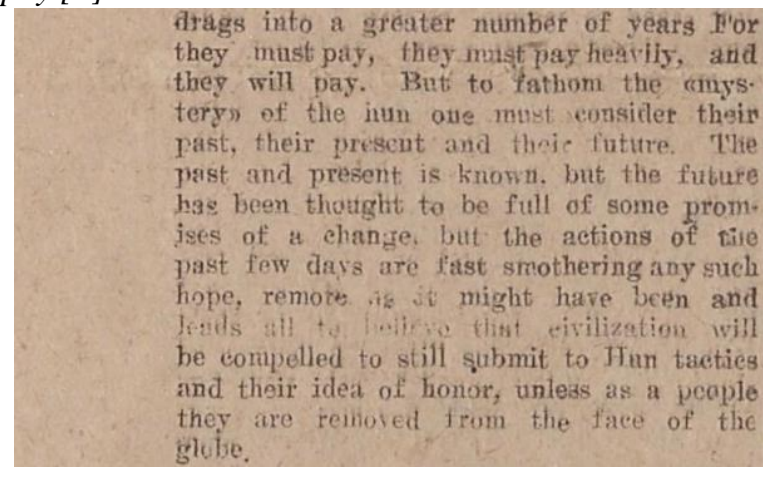

Appendix II. The original text of Article 231 [7]

$$
\text { PART VIII. }
$$

REPARATION

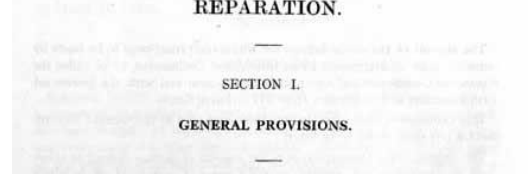


Appendix III. Germany was forced to pay high war reparation payments [20]

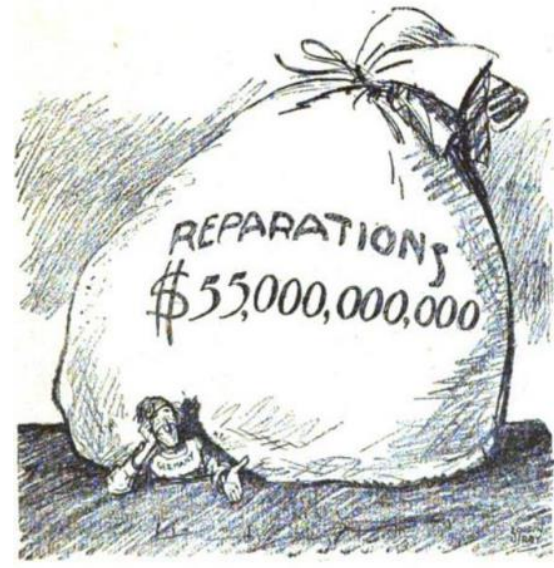

Appendix IV. The territorial changes of Germany after the Treaty of Versailles [14]

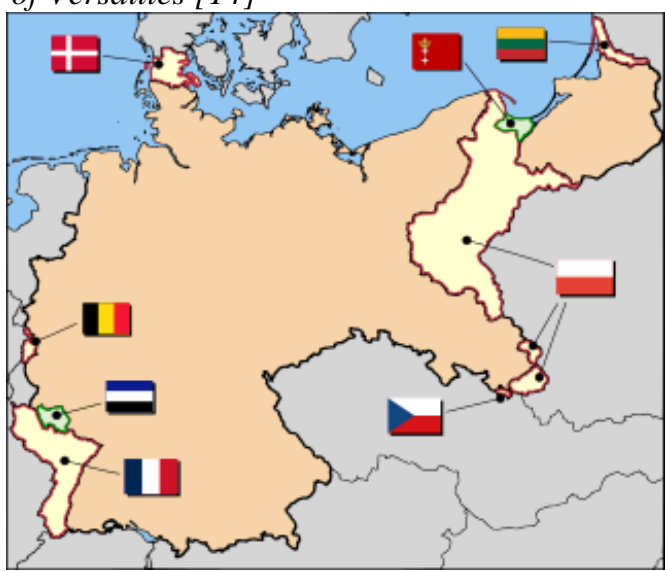

Appendix V. The map of the Polish corridor and the free city of Danzig [12]

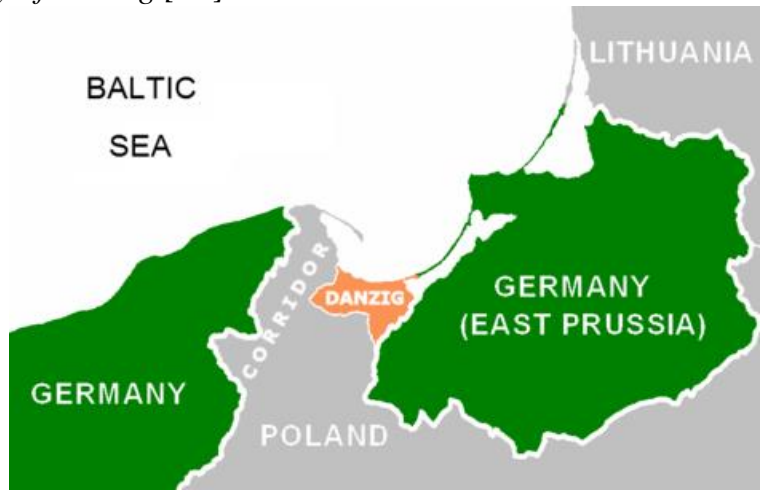

\section{ACKNOWLEDGMENT}

The completion of this undertaking would not have been possible without the participation and cooperation of $\mathrm{Mr}$. Charlie Malcolm, who gave the author a golden opportunity to do this project. The author learned many new information upon the completion of this paper.

\section{REFERENCES}

[1] "Aspects of the War Guilt Clause \& What It Tells Us." Betterhelp. BetterHelp, October 23, 2018.

https://www.betterhelp.com/advice/guilt/aspects-of-the-war-guiltclause-what-it-tells-us/.

[2] Barnes, Harry Elmer. "The Public Significance of the War-Guil Question." The ANNALS of the American Academy of Political and Social Science 175, no. 1 (1934): 11-18. https://doi.org/10.1177/000271623417500103.

[3] Blog, Editorial. "Home." Adam Matthew Digital, https://www.amdigital.co.uk/about/blog/item/the-treaty-of-versaillesdiffering-perspectives.

[4] Boden, Michael A., and Robert T. Foley. "Versailles Treaty: Was the Treaty of Versailles Responsible for the Rise of Hitler and Nazism in Germany?" History in Dispute, edited by Dennis Showalter, vol. 4: World War II, 1939-1943, St. James Press, 2000, pp. 266-274. Gale In Context: World History, https://link.gale.com/apps/doc/CX2876400043/WHIC?u=mlin_w_nth field \&sid=WHIC\&xid=74fbe302. Accessed 29 Nov. 2019.

[5] "Dawes Plan." Europe Since 1914: Encyclopedia of the Age of War and Reconstruction, edited by John Merriman and Jay Winter, vol. 2 , Charles Scribner's Sons, 2006, pp. 776-778. Gale In Context: World History,

https://link.gale.com/apps/doc/CX3447000256/WHIC?u=mlin_w_nth field\&sid=WHIC\&xid=bc37d1bc. Accessed 24 Nov. 2019.

[6] "Describe How the Treaty of Versailles Weakened Germany: a. Through the Loss of Territory, b. Militarily, c. Economically." ToV \& Germany. Accessed November 20, 2019 https://www.johndclare.net/EA2.htm.

[7] First World War. Accessed November 25, 2019 http://www.nationalarchives.gov.uk/pathways/firstworldwar/aftermat $\mathrm{h} / \mathrm{p} \_$versailles.htm

[8] "German Inflation 1919-1923." הספרייה הלאומית. Accessed November 21 , 2019. https://web.nli.org.il/sites/nli/english/collections/personalsites/israelgermany/weimar-republic/pages/inflation.aspx.

[9] "How Did the Versailles Treaty Lead to World War Two?" How did the Versailles Treaty lead to World War Two? - DailyHistory.org. Accessed November 2019. https://dailyhistory.org/How_did_the_Versailles_Treaty_lead_to_Wor ld_War_Two?

[10] Judt, Tony. "We'll Always Have Paris." The New York Times. The New York Times, December 1, 2002. https://www.nytimes.com/2002/12/01/books/we-ll-always-haveparis.html.

[11] National Archives. "The National Archives Learning Curve: The Great War: Why Was It Hard to Make Peace?" The National Archives. The National Archives, January 27, 2004 https://www.nationalarchives.gov.uk/education/greatwar/g5/cs2/back ground.htm.

[12] "Polish Corridor." Wikipedia. Wikimedia Foundation, November 30 2019. https://en.wikipedia.org/wiki/Polish_Corridor.

[13] Ryan. "Keynes and the Versailles Treaty's Infamous 'Article 231' Edward W. Fuller." Mises Institute, April 2, 2019 https://mises.org/wire/keynes-and-versailles-treatys-infamous-article231.

[14] "Territorial Evolution of Germany." Wikipedia. Wikimedia Foundation, December 2019 https://en.wikipedia.org/wiki/Territorial_evolution_of_Germany.

[15] "The Aftermath of the First World War." The Treaty of Versailles The Holocaust Explained: Designed for schools. Accessed November 12, 2019. https://www.theholocaustexplained.org/the-nazi-rise-topower/the-effects-of-the-first-world-war-on-germany/the-treaty-ofversailles/.

[16] "Treaty of Versailles." Gale World History Online Collection. Gale In Context: World History. Accessed November 20, 2019. https://link.gale.com/apps/doc/DSWFJQ191999627/WHIC?u=mlin w_nthfield\&sid=WHIC\&xid=4282127d. Accessed 20 Nov. 2019.

[17] "Versailles Treaty: Did the Versailles Treaty (1919) Precipitate the Rise of Nazism?" History in Dispute, edited by Paul du Quenoy, vol. 16: Twentieth-Century European Social and Political Movements: Firs Series, St. James Press, 2004, pp. 291-297. Gale In Context: World History,

https://link.gale.com/apps/doc/CX2877600048/WHIC?u=mlin_w_nth field\&sid=WHIC\&xid=5f25b67d. Accessed 30 Nov. 2019.

[18] "Weimar Germany 1918-1924 - AQA - Revision 2 - GCSE History BBC Bitesize.” BBC News. BBC. Accessed November 20, 2019. https://www.bbc.co.uk/bitesize/guides/z8vt9qt/revision/2. 
[19] "Why Was There Opposition in Germany to the Treaty of Versailles?" Why G Hated ToV. Accessed December 2, 2019. https://www.johndclare.net/EA3.htm.

[20] Woodbridge, Steven. "World War I: Is It Right to Blame the Treaty of Versailles for the Rise of Hitler?" The Conversation, June 3, 2019. http://theconversation.com/world-war-i-is-it-right-to-blame-thetreaty-of-versailles-for-the-rise-of-hitler-106373.

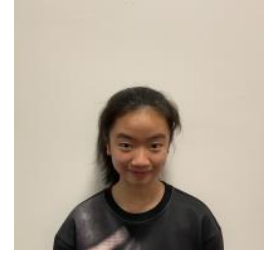

Stella Zhu was born in New Zealand on January 8th, 2004. She is from Hong Kong and Shenzhen, China. She currently studies at Northfield Mount Hermon School, MA, United States.

She has worked as an intern at an educational company, teaching pre-schoolers English. She is interested in American and European history. Ms. Zhu has published two of her historical essays in Young Scholars Journal. 